\title{
The late glacial-Holocene transition as inferred from ostracod and pollen records in the Lago Piccolo di Avigliana (Northern Italy)
}

\author{
Claudio A. Belis ${ }^{\mathrm{a}, *}$, Walter Finsinger ${ }^{\mathrm{b}, \mathrm{c}}$, Brigitta Ammann ${ }^{\mathrm{b}}$ \\ a via Pace 19, 23020 Montagna in Valtellina (SO), Italy \\ b Institute of Plant Sciences, University of Bern, Altenbergrain 21, CH 3013 Bern, Switzerland \\ ' Palaeoecology, Institute of Environmental Biology, University of Utrecht, Laboratory of Palaeobotany E' Palynology, Budapestlaan 4, 3584 CD Utrecht, The Netherlands
}

\section{A R T I C L E I N F O}

\section{Article history:}

Accepted 10 January 2008

Keywords:

Ostracods

Pollen

Late glacial-Holocene transition

Northern Italy

Ordination

\begin{abstract}
A B S T R A C T
Ostracod and pollen records of Lago Piccolo di Avigliana were used for the reconstruction of aquatic and terrestrial palaeoenvironments between 17 and $10 \mathrm{kyr}$ cal BP.

A combination of multivariate ordination techniques (PCA and RDA) made it possible to describe ostracod and pollen biostratigraphies and to evaluate whether changes in the aquatic ecosystem were associated with those in the terrestrial environments. Samples and taxa in the ordination plots were grouped into three clusters: a first cluster representing herbaceous and shrub pollen taxa (Juniperus, Chenopodiaceae, Gramineae, Artemisia, and Rubiaceae) associated with ostracods typical of oligotrophic and well oxygenated aquatic environments (Cytherissa lacustris), a second cluster containing pollen taxa representing boreal forests (Betula, Pinus sylvestris, and Pinus cembra) associated with ostracod taxa from shallow oligomesotrophic aquatic environments (Candona candida, Darwinula stevensoni), and a third cluster including pollen of thermophilous trees and shrubs (Corylus, Quercus ilex, Fraxinus, Quercus robur-type, and Ulmus) connected to ostracods representing warm mesotrophic aquatic conditions with aquatic vegetation (Cypria ophtalmica, Metacypris cordata). Hypothesis testing with constrained Monte Carlo permutations rejected the null hypothesis that no relationship exists between ostracod and pollen datasets at $2 \%$ level of significance. As a whole, changes in temperature and precipitation-evaporation balance that influenced terrestrial vegetation were represented by changes in trophic level and water level in the aquatic environment.
\end{abstract}

(c) 2008 Elsevier B.V. All rights reserved.

\section{Introduction}

The autoecology of animal and plant species has proven to be a useful tool to estimate trends and changes in past environmental conditions. In the case of non-marine ostracods (Crustacea), an increasing number of studies provide quantitative estimates of the tolerance and optima to environmental factors (e.g. temperature, salinity, and ion concentrations) (Nüchterlein, 1969; Hiller, 1972; Curry, 1999; Mezquita et al., 1999). These estimates are the basis for palaeoecological reconstructions of water salinity (Anadón et al., 1986), trophic state of lakes (Scharf, 1998; Meisch, 2000), meromixis (Löffler, 1997), and lake-water level changes (Colman et al., 1994; Mourguiart and Carbonel, 1994).

Environmental data are in general abundant, complex, redundant, and rich in internal relationships. Their subjective interpretation may overlook intrinsic aspects that are not readily evident (Jongman et al., 1987). Nevertheless, the development of multivariate-analysis techniques makes it possible to handle a large amount of quantitative data in order to explore the underlying patterns that drive environmental

\footnotetext{
* Corresponding author. Tel.: +39 0342381015.

E-mail addresses: claudio.belis@provincia.so.it, claudio.belis@alice.it (C.A. Belis).
}

factors and changes in species composition (ter Braak and Prentice, 1988). Modern ordination techniques construct theoretical variables (explanatory variables), which maximize the variance of the species data assuming either linear or unimodal responses.

In indirect gradient analysis the theoretical variables are computed considering only the abundance of the species (response variables). Comparisons with the observed environmental variables for the interpretation of the theoretical variables are made separately. On the other hand, in the case of direct gradient analysis the theoretical variables are a combination of both response and environmental variables.

The main output of ordination techniques is a two dimensional diagram representing sites (or depths). The axes of the diagram represent the theoretical variables that better explain the dispersion of species scores. Points that are close in the diagram stand for sites (depths) with similar species composition.

The present study aims to establish whether changes in the aquatic environment estimated on the basis of ostracod biostratigraphy matched changes in the terrestrial environment as inferred from pollen assemblages. The late glacial-Holocene transition is particularly appropriate for this purpose for it represents the highest amplitude of climatic and environmental change since the end of 


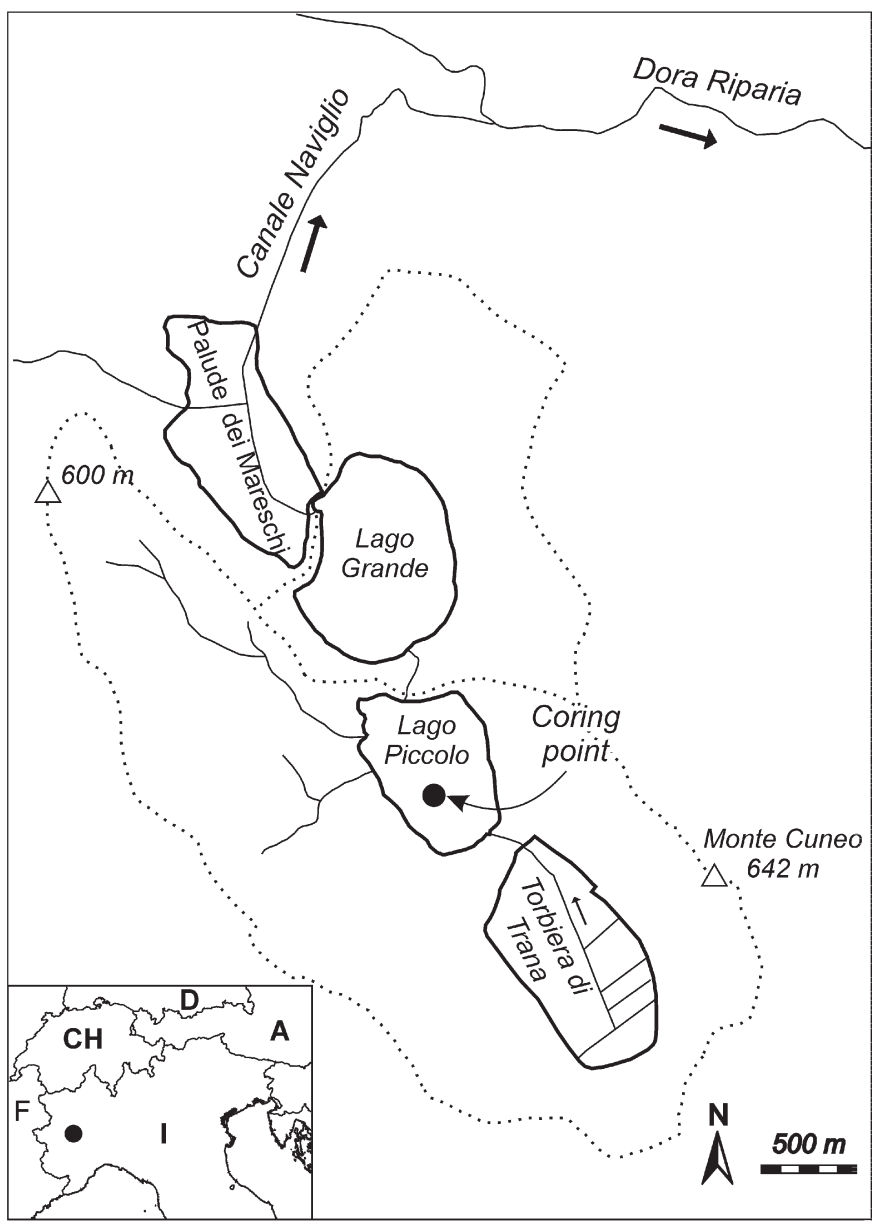

Fig. 1. Location of Lago Piccolo di Avigliana. Continuous line: surface hydrology; dotted line: limits of hydrological catchment.

the last glacial maximum (Lowe, 2001; Lotter, 2004) making it possible to evaluate changes of considerable amplitude in the terrestrial and in the aquatic ecosystems.

\section{Study site}

Lago Piccolo di Avigliana $\left(45^{\circ} 03^{\prime} \mathrm{N}, 07^{\circ} 23^{\prime} \mathrm{E}\right)$ lies in the southern foothills of the Alps in northwestern Italy in a north-south oriented lateral valley of the Val di Susa (Fig. 1). The ca. $0.6 \mathrm{~km}^{2}$ lake, located at
$350 \mathrm{~m}$ a.s.l., is surrounded in its catchment $\left(8.1 \mathrm{~km}^{2}\right)$ by hilltops lower than $1000 \mathrm{~m}$ a.s.l., which provide a sheltered position from southern winds. Lake mean and maximum depths are 7.7 and $12 \mathrm{~m}$ respectively. The mean lake-water volume is $4.5 \times 10^{6} \mathrm{~m}^{3}$ and its residence time is $0.9 \mathrm{yr}$ (Gaggino and Cappelletti, 1984).

The lake is dammed by a last glacial maximum (LGM)-moraine system deposited by a lateral tongue of the Val di Susa valley glacier (Petrucci et al., 1970). During the Younger Dryas glaciers were confined to small cirques located exclusively outside the hydrological catchment of the lake (Carraro et al., 2002).

Mean annual temperature at Avigliana is $13.0{ }^{\circ} \mathrm{C}$, and mean temperatures of the coldest and warmest months are $2.2{ }^{\circ} \mathrm{C}$ (January) and $23.9{ }^{\circ} \mathrm{C}$ (July), respectively (Biancotti et al., 1998). Mean annual precipitation is $880 \mathrm{~mm}$, with rainfall distributed mainly in autumn and in spring (Biancotti et al., 1998), following the activity of the Genoa Low.

\section{Materials and methods}

The lake sediments were cored with a modified piston corer (Merkt and Streif, 1970) from a floating platform at the center of the lake (12 m water depth) in autumn 2001. Meter-long drives were transferred into plastic half-tubes, wrapped in plastic foil, transported to the laboratory, stored at $4{ }^{\circ} \mathrm{C}$ in a dark room, and then sub-sampled.

The chronology is given by 10 radiocarbon dates on terrestrial plant macrofossils and by the Laacher See Tephra (LST), which was extracted and geochemically fingerprinted by Blockley et al. (2005). The age-depth model was calculated with a non-parametric locally weighted least squares regression (LOWESS; span $=0.3$; order $=1$ ) (Finsinger et al., 2006). For the LST an age of 12,900 cal yrs BP was adopted, following Baales et al. (2002). This age scarcely differs from the 12,836 GRIP years age obtained by Schwander et al. (2000) for the Gerzensee and Leysin records. Sediment changes in the analysed core are described in Finsinger (2004).

For the ostracod analysis, 10-20 g of wet sediment was sieved through a $200 \mu \mathrm{m}$ mesh. All ostracod remains were picked out and counted under a binocular microscope (magnification 20x-100x) (Van Morkhoven, 1962). Sample volume was determined by water displacement.

In order to estimate maximum environmental variability, ostracod analysis was carried out on selected samples with respect to major changes in lithology, loss-on-ignition, and pollen biostratigraphy (Finsinger, 2004).

No chemical treatment was used to separate the valves from the sediment (Belis et al., 1999). Taxonomic determinations were carried out according to Meisch (2000) and were documented by SEM photographs (not shown). The absolute abundance of valves (adults and juveniles) is expressed as valves per cubic centimetre of sediment.

Samples for pollen analysis $\left(1 \mathrm{~cm}^{3}\right)$ were prepared physically (decanting, sieving at $500 \mu \mathrm{m}$ ) and chemically $(\mathrm{HCl}, \mathrm{KOH}, \mathrm{HF}, \mathrm{HCl}$,

Table 1

List of ostracod and pollen taxa used in the multivariate analyses

\begin{tabular}{|c|c|c|c|}
\hline Ostracod taxa & Code & Pollen taxa & Code \\
\hline Candona candida (O.F. Müller, 1776) & C CAN & Alnus glutinosa & ALN GLT \\
\hline Candoninae sp. & CAND & Betula & BETULA \\
\hline juv. Candoninae & JUV CAN & Corylus avellana & CORYL AV \\
\hline Cyclocypris sp & CYC SP & Fraxinus excelsior & FRAX EXC. \\
\hline Cypria ophtalmica (Jurine, 1820) & CYP & Juniperus & JUNIPER. \\
\hline juv. Cypria & JUV CYP & Larix spp. & LARIX \\
\hline Potamocypris sp. & POT & Pinus cembra & PIN. CEMB. \\
\hline Herpetocypris sp. & HER SP & Pinus sylvestris type & PIN DIPL. \\
\hline Cytherissa lacustris (Sars, 1863) & CYT & Quercus pubescens & QUER. PUB. \\
\hline juv. Cytherissa lacustris & JUV CYT & Quercus ilex & QUER. ILX. \\
\hline Metacypris cordata Brady \& Robertson, 1870 & MTC & Ulmus spp. & ULMUS \\
\hline Limnocytherinae sp. & LYM & Artemisia & ARTEMIS \\
\hline \multirow[t]{5}{*}{ Darwinula stevensoni (Brady \& Robertson, 1870) } & DAR & Chenopodiaceae type & CHENOP. T. \\
\hline & & Poaceae & GRAMINE. \\
\hline & & Rubiaceae & RUBIACE \\
\hline & & Rumex acetosa/acetosella type & RUM. ACET. \\
\hline & & Pinus stomata & PINUS ST. \\
\hline
\end{tabular}


Table 2

Summary of ordination analyses on ostracod and pollen datasets

\begin{tabular}{|c|c|c|c|c|c|c|c|c|}
\hline $\begin{array}{l}\text { Ordination } \\
\text { technique }\end{array}$ & Dataset & $\begin{array}{l}\text { Gradient } \\
\text { analysis }\end{array}$ & $\begin{array}{l}\text { Response } \\
\text { model }\end{array}$ & $\begin{array}{l}\text { 1st axis explained } \\
\text { variance (\%) }\end{array}$ & $\begin{array}{l}\text { 2nd axis explained } \\
\text { variance (\%) }\end{array}$ & Taxa & Samples & $\begin{array}{l}\text { Environmental } \\
\text { variables }\end{array}$ \\
\hline$\overline{C A}$ & Ostracod & Indirect & Unimodal & 46 & 15 & 13 & 21 & \\
\hline PCA & Ostracod & Indirect & Linear & 58 & 23 & 13 & 21 & \\
\hline DCA & Terr. pollen & Indirect & Unimodal & 45 & 15 & 17 & 21 & \\
\hline PCA & Terr. pollen & Indirect & Linear & 56 & 33 & 17 & 21 & \\
\hline CCA & Ostr. and terr. pollen & Direct & Unimodal & 40 & 9 & 13 & 21 & 5 \\
\hline RDA & Ostr. and terr. pollen & Direct & Linear & 48 & 10 & 13 & 21 & 5 \\
\hline CCA & Ostr. and aq. pollen & Direct & Unimodal & 41 & 3 & 13 & 21 & 4 \\
\hline RDA & Ostr. and aq. Pollen & Direct & Linear & 32 & 6 & 13 & 21 & 4 \\
\hline
\end{tabular}

Acetolysis, $\mathrm{KOH}$ ) and were embedded in glycerine following Lotter (1988). Identification of pollen grains was conducted at 400× with the aid of identification keys (Moore and Webb, 1978; Punt et al., 19761996) and photographic collections (Reille, 1992). Conifer stomata were identified following Trautmann (1953). At least 400 pollen grains of terrestrial plants were counted. Percentages were calculated upon the terrestrial pollen sum including tree, shrub, herb, and fern pollen. Pollen concentration was calculated by means of added Lycopodium spores (Batch number 938934) following Stockmarr (1971).

\subsection{Ordination techniques}

In order to compare the two records, only samples between 881 and $654 \mathrm{~cm}$ core depth containing both ostracod and pollen data were included in the numerical analyses $(n=21$;). Ordination analyses and
Monte Carlo tests were performed with the program CANOCO version 4.52 (ter Braak and Šmilauer, 2003).

\subsection{Indirect gradient analysis}

The ostracod dataset included 13 selected taxa. Rare species with low frequency (present in less than two samples) were excluded (Table 1). For the analysis of the pollen record, a reduced dataset with 17 selected taxa was used. These 17 pollen taxa were chosen because their abundances show the highest variability within the studied time window, and were, therefore, expected to provide more information about environmental changes.

The length of the gradient was estimated by means of a preliminary DCA. These datasets were then analysed separately by Correspondence Analysis (CA) and a Principal Component Analysis (PCA). In both cases PCA

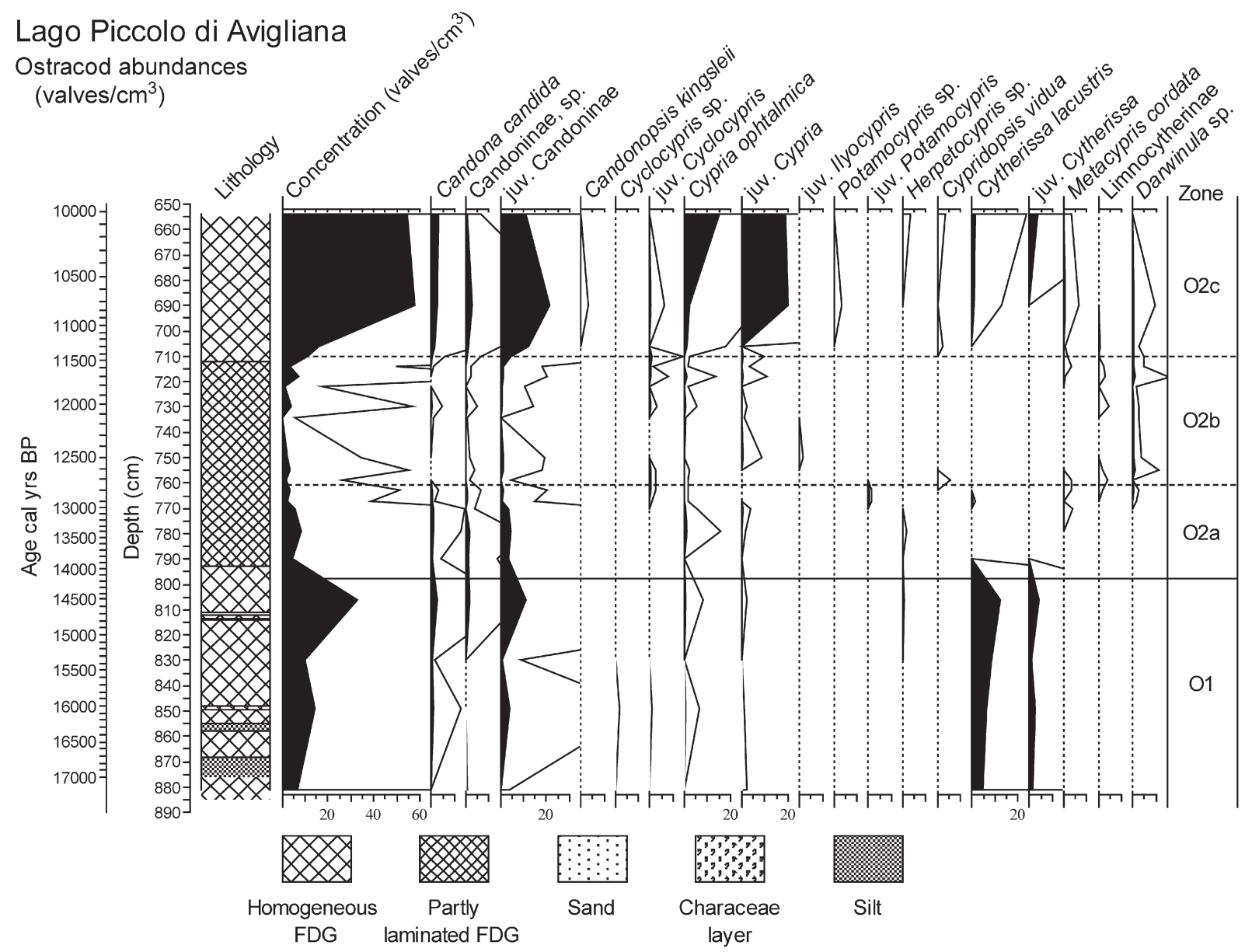

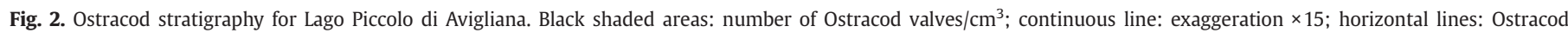
assemblage zone limits. FDG = fine detritus gyttia. 


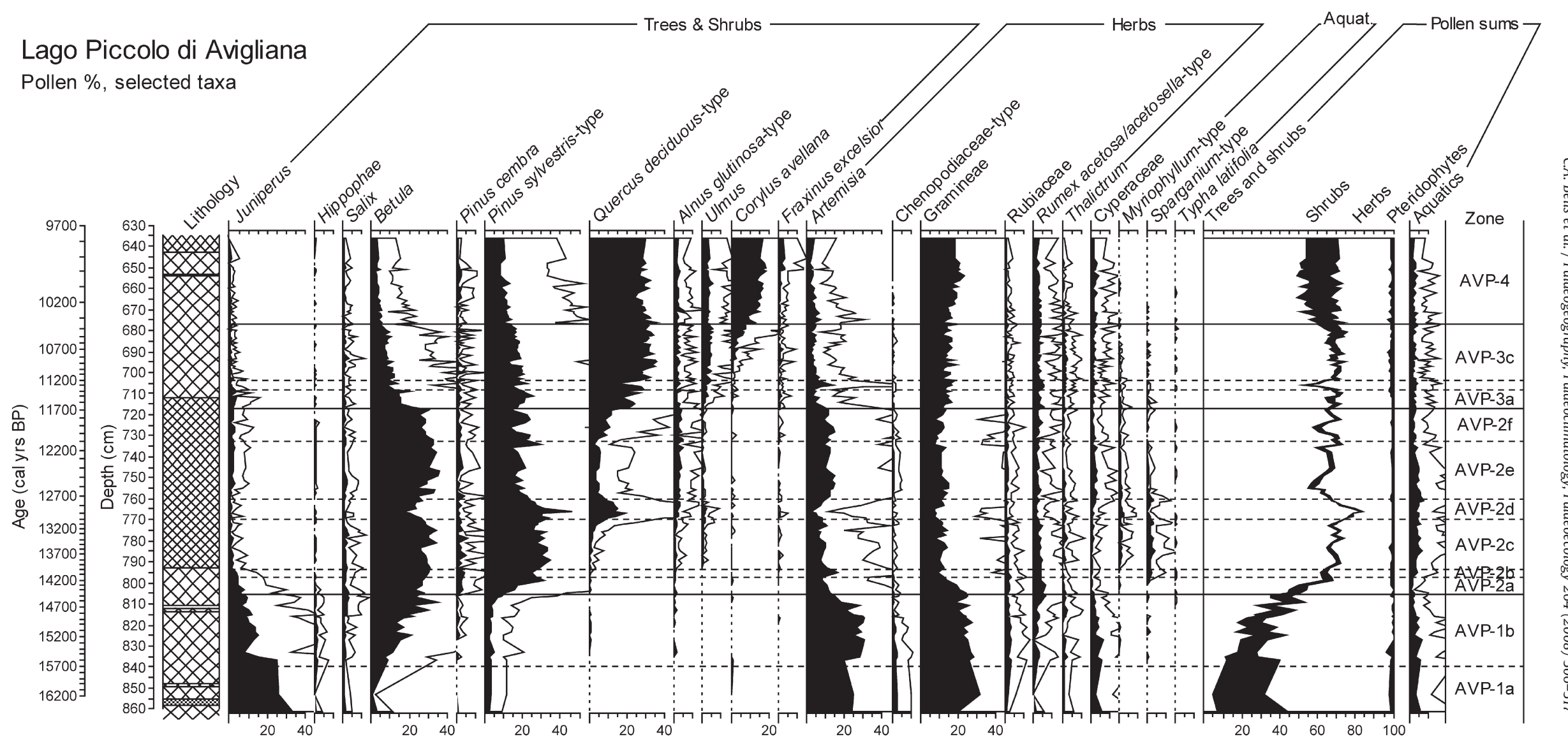

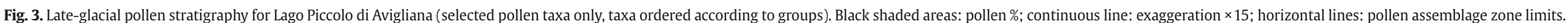
For lithology legend see Fig. 2. 
(linear response model) performed better, in terms of explained variance, than CA and DCA (unimodal response model) (Table 2). Sample and species scores were reported in covariance biplots (Corsten and Gabriel, 1976).

\subsection{Direct gradient analysis}

In order to distinguish variations in the aquatic environment from external factors, terrestrial and aquatic pollen were treated separately. Canonical analyses were carried out with ostracods as response variables and pollen as environmental variables, an approach similar to the one used by Anderson et al. (1996) to estimate the influence of agricultural activity on diatom assemblages.

In direct gradient analyses, the exclusion of redundant environmental variables is strongly advisable in order to allow as tight as possible restrictions on response variables (Jongman et al., 1987). Hence, in order to identify relationships among pollen taxa and then to exclude redundant variables, the reduced pollen dataset was pre-processed with a two-step procedure. First a Hierarchical Cluster Analysis (HCA) was computed with a cutoff level based on the correlation coefficient distance $(r=0.4)$, to identify clusters of pollen taxa. Then the number of pollen taxa was reduced with a forward selection procedure, and significance of each pollen taxon was tested by Monte Carlo permutation tests (Manly, 1992). In this way a reduced number of pollen taxa was obtained, each one representing, in a statistical sense, the cluster to which it belonged. One representative of each cluster chosen by forward selection was included in the canonical analysis.
As was the case for the indirect gradient analysis (Table 2), the linear response model (redundancy analysis; RDA), performed better than the unimodal model (Canonical correspondence analysis; CCA).

\subsection{Zonation}

In order to apply quantitative criteria, zonation of the ostracod and pollen diagrams was also carried out by optimal sum of squares partition (Birks and Gordon, 1985). The significance of zones was thereafter assessed against a model of random partitioning of the stratigraphical sequence using the simple broken-stick model, following Bennett (1996). In addition to these boundaries, zones were also visually defined by the operator on the basis of major changes in species composition and abundance. In the ostracod and pollen diagrams, statistically significant zones are shown as continuous lines, while other boundaries are shown as dashed lines. Local pollen assemblage zones should not be considered as chronozones (Mangerud et al., 1992) but as biozones, following Ammann et al. (2000).

\section{Results}

\subsection{Ostracod and pollen biostratigraphies}

The first ostracod biozone ( 01 ; > 14,200 cal yr BP) was dominated by Cytherissa lacustris and Candona candida (Fig. 2). A gradual afforestation is inferred from the increase of Betula pollen starting

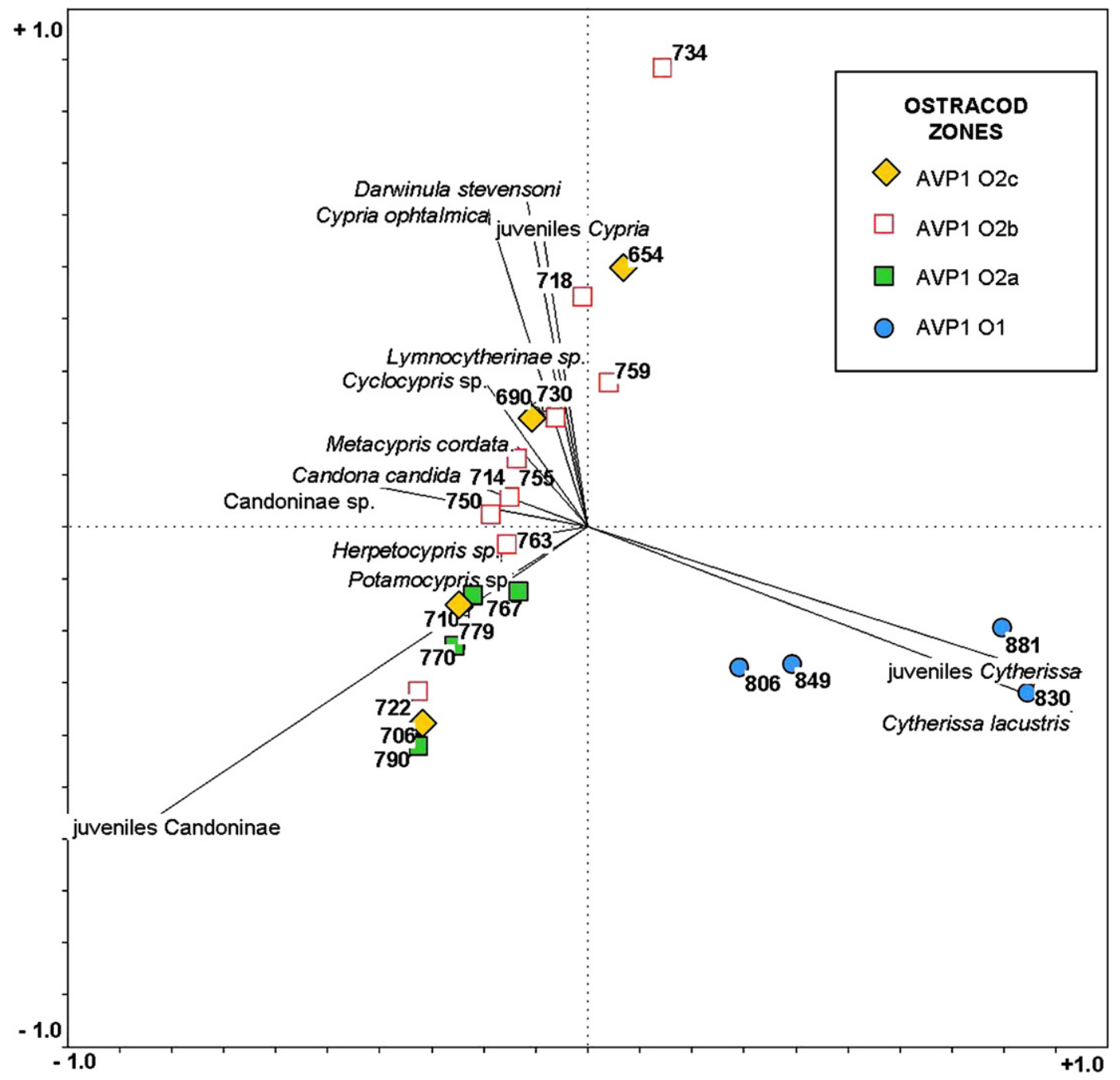

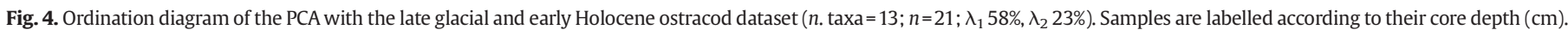




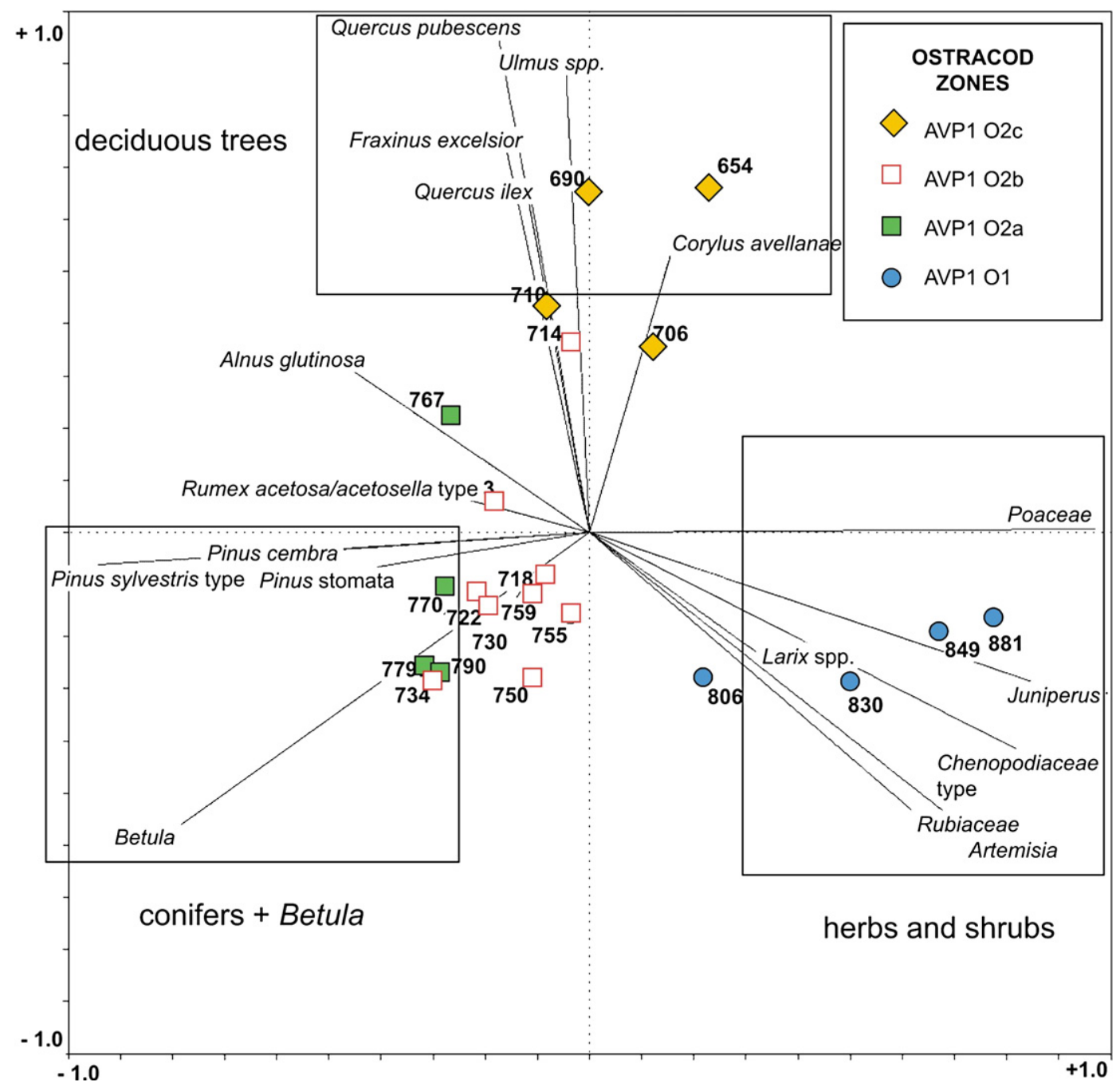

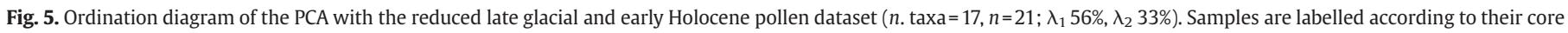
depth $(\mathrm{cm})$. Sets of similar species are bounded by continuous lines.

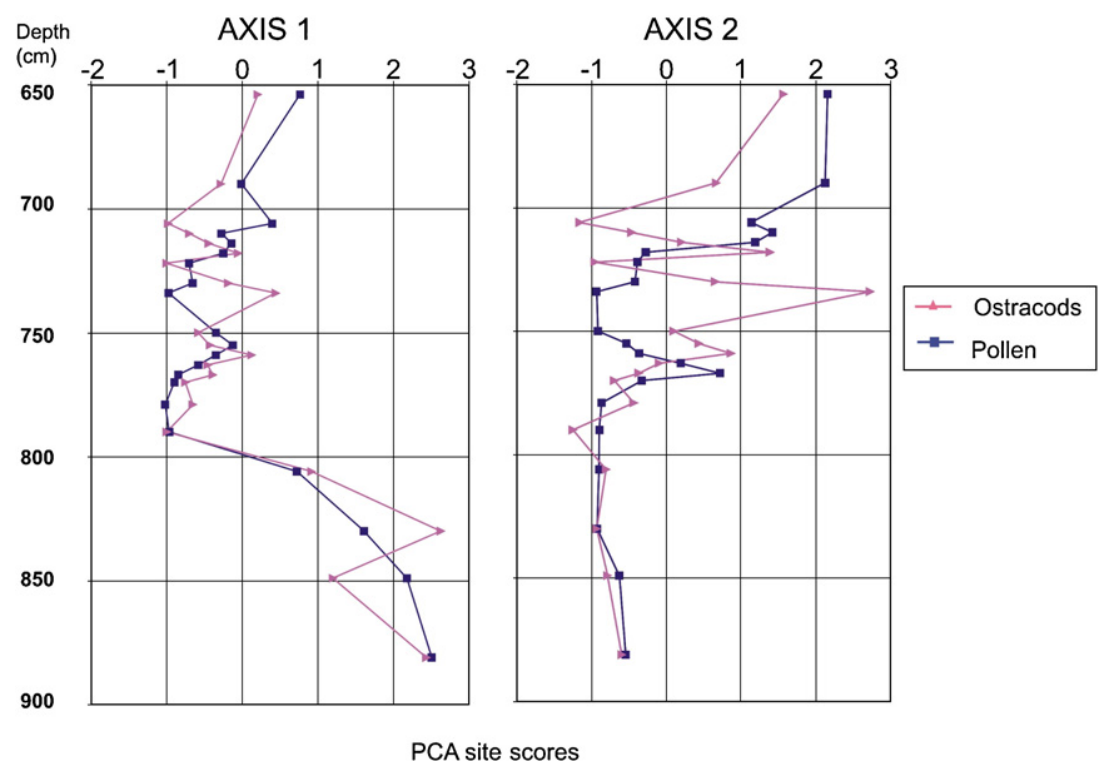

Fig. 6. Site scores on the first and second PCA axes on both ostracod and pollen datasets $(n=21)$ reported in stratigraphical order. 
prior to 14,200 cal yr BP, while a more rapid increase of Pinus pollen (onset zone AVP-2a) probably indicates a more rapid population expansion (Fig. 3). At $\sim 14,500$ cal yr BP a peak in the total abundance of ostracods occurred without changes in species composition and in sediment lithology.

At the beginning of subzone $02 \mathrm{a}(14,200-12,750 \mathrm{yr} \mathrm{BP})$ the total concentration of valves decreased, numbers of C. lacustris were strongly reduced, and C. candida and Cypria ophtalmica dominated the ostracod assemblage. The continuous presence of low percentages of Quercus pollen suggests the presence of the tree at low population densities in the catchment (subzones AVP-2a to AVP-2c). Subsequently, an expansion of thermophilous trees (Quercus and Ulmus) occurred (subzone AVP-2d), while Pinus remained stable at high levels.

A further strong decrease of both total valve concentration and ostracod species abundance occurred between 12,750 and $11,450 \mathrm{cal}$ yr BP (subzone O2b - Younger Dryas). Darwinula stevensoni and $\mathrm{Me}$ tacypris cordata occurred especially at the beginning and at the end of this subzone. During the Younger Dryas, pollen of arboreal taxa decreased while shrub and herbaceous taxa (i.e. Juniperus, Artemisia and Chenopodiaceae) increased (subzone AVP-2e and AVP-2f).

At the onset of the Holocene (subzone 02c; 11,450-10,100 cal yr BP) total valve abundance increased. After an abrupt increase $C$. candida was progressively exceeded by $C$. opthalmica. At the top of the sequence, $C$. lacustris presented an increasing trend, whereas $D$. stevensoni decreased. Quercus and Ulmus were the first thermophilous trees to re-expand at the onset of the Holocene (subzone AVP-3a), and they were followed by Corylus (subzone AVP-3c).

In general, preservation of ostracod valves is good with no sign of valve decalcification. Therefore it can be excluded that changes in the total abundance of ostracods (Fig. 2) were influenced by poor valve preservation.

In order to evaluate whether the pool of ostracods in the sediments (thanatocoenosis sensu Boomer et al., 2003) represents an autochthonous living biocoenosis or is the result of post-mortem transport, an analysis of the structure of the population was carried out on $C$. candida, the most abundant species throughout the sequence. The ratio adult to juvenile valves (stages A-1 to A-3) is in general relatively constant (mean $0.3 \pm 0.1$ ) and close to 0.3 , the expected value for autochthonous thanatocoenosis (Boomer et al., 2003; Fig. 2). However, in the middle of zone $\mathrm{O} 2 \mathrm{~b}$, where the total valve abundance was low, post-mortem transport of the valves cannot be excluded.

\subsection{Numerical analyses}

The biplot in Fig. 4 represents the first and second axis of the PCA on the ostracod dataset (13 selected taxa). The length of the gradient, as estimated from DCA, is 3.1. The first two principal components explain $58 \%$ and $23 \%$ of the total variance, respectively.

The first axis is mainly related to the abundance of $C$. lacustris. The second axis, instead, represents a transition of samples containing $C$. ophtalmica, D. stevensoni, Limnocythere sp., Cyclocypris sp., and M. cordata to samples with $C$. candida and Herpetocypris sp. (Potamocypris $\mathrm{sp}$. is a minor component). In the PCA biplot, plots of samples belonging to zone $\mathrm{O} 1$ are closely related to each other and are well segregated from those of other zones, while samples of subzones 02a cluster in a small area of the biplot but overlap with samples of other subzones. Plots of samples in subzones $\mathrm{O} 2 \mathrm{~b}$ and $\mathrm{O} 2 \mathrm{c}$ present a strong dispersion with respect to the second axis and marginally overlap samples of other subzones.

Main changes in the pollen assemblages are summarized in the PCA biplot (Fig. 5). The length of the gradient estimated from DCA is 2.0 , and the first and second axes explain $56 \%$ and $33 \%$ of the species data variance, respectively.

Herbs are well segregated from arboreal taxa along the first axis, whereas thermophilous tree taxa are segregated from the other taxa

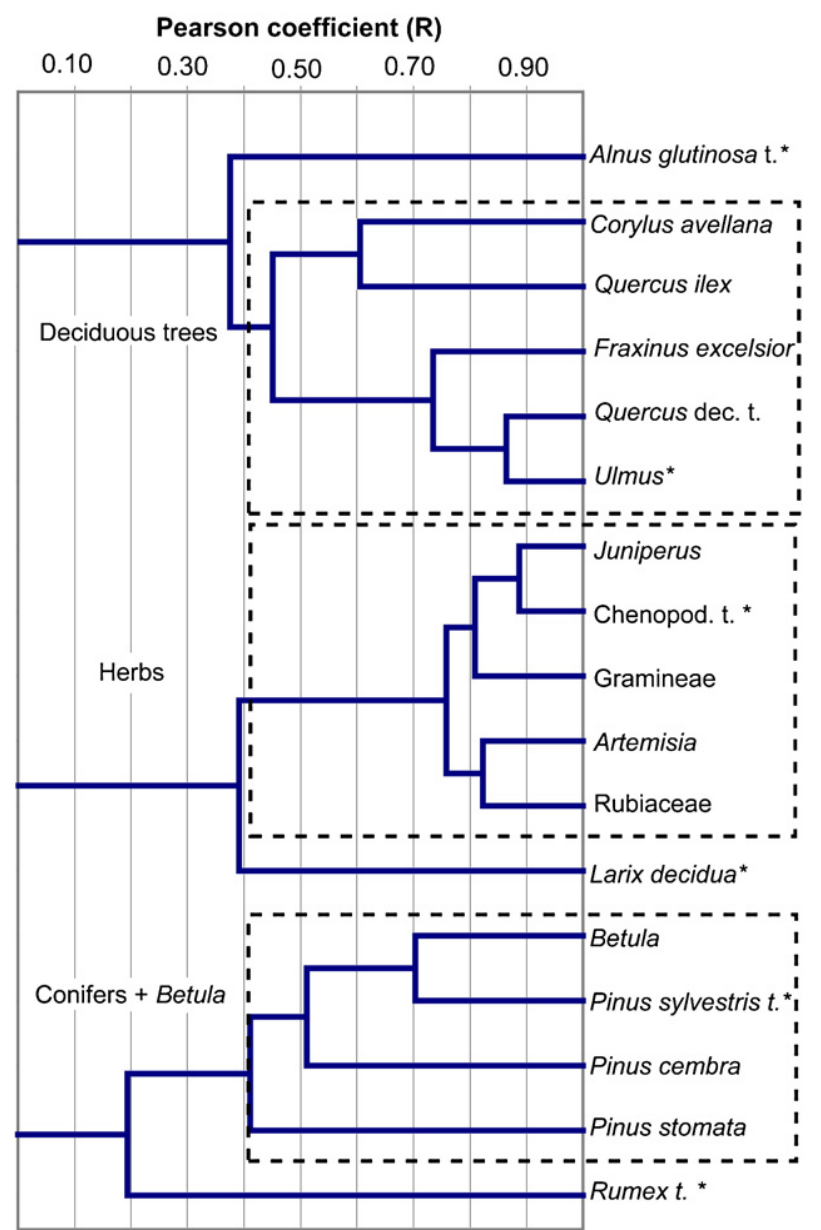

Fig. 7. Hierarchical Cluster Analysis (HCA) on terrestrial pollen taxa ( $n$. taxa $=17, n=21$; Pearson coefficient distances, average linkage). Sets of similar species are bounded by dotted lines. Representative taxa of each cluster chosen by forward selection (with Monte Carlo permutation tests) are marked with an asterisk.

along the second axis. The projections of the loadings of Pinus and Betula on this axis fall close to those of the herbaceous taxa (e.g. Artemisia, Rubiaceae).

In order to compare the main changes in the ostracod and pollen assemblages from a stratigraphical point of view, sample scores were plotted against core depth (Fig. 6). Scores in ostracod and pollen assemblages along the first axis are more comparable than changes of sample scores along the second PCA axes, in particular between 734 and $706 \mathrm{~cm}$ core depth.

In order to reduce the number of pollen taxa for the direct gradient analyses, the output of the Hierarchical Cluster Analysis (HCA) was cut at the 0.4 level (Fig. 7). Pollen taxa were grouped in six clusters, three of which were formed by a single taxon (Alnus glutinosa, Larix and Rumex actosa/acetosella type). The three main clusters grouped thermophilous tree and shrub taxa (Corylus, Quercus ilex, Fraxinus, Quercus robur-type, and Ulmus), herb taxa (Juniperus, Chenopodiaceae, Gramineae, Artemisia, and Rubiaceae), and boreal tree taxa (Betula, Pinus sylvestris, and Pinus cembra), respectively.

The forward selection procedure (with Monte Carlo permutation test) on the same pollen dataset singled out 5 taxa $(p \leq 0.12)$ each one of which represented one of the clusters resulting from the HCA, except for the unitary cluster with Larix (Fig. 7). In this way, a set was obtained of the few species that explain the variance of the whole pollen dataset.

In order to analyse the relationship between ostracod and pollen assemblages, a redundancy analysis (RDA) was computed with a 


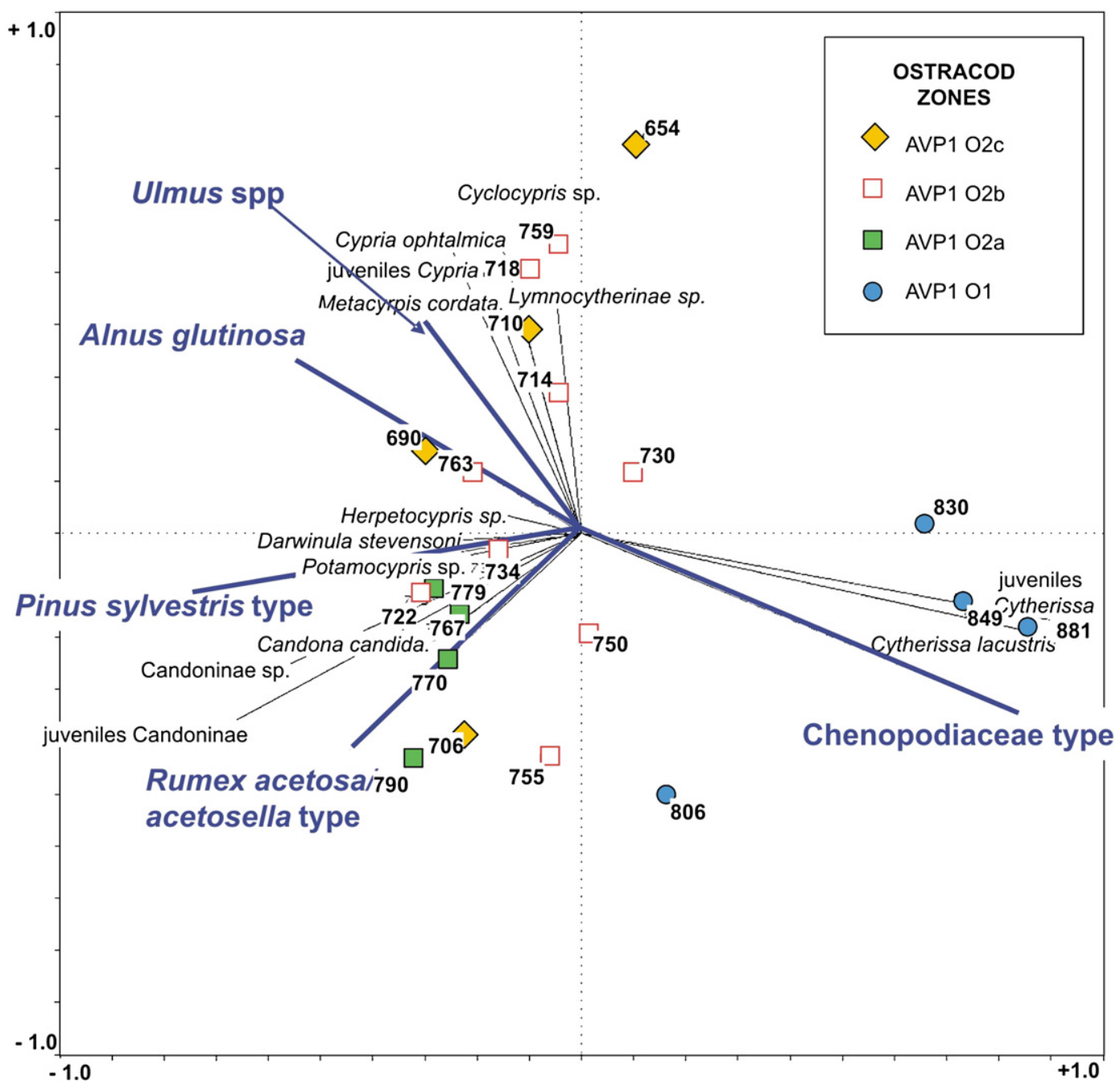

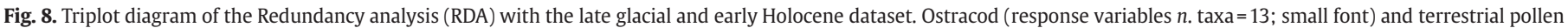
(explanatory variables $n$. taxa $=17$; large bold font), $n=21 ; \lambda_{1} 48 \%, \lambda_{2} 10 \%$. Samples are labelled according to their core depth (cm).

dataset of 13 ostracod taxa (response variables) and 5 pollen taxa (environmental variables) selected in the previous step (Fig. 8). The first and second canonical axes account for $48 \%$ and $10 \%$ of the variance, respectively. The ratio $\lambda_{1}+\lambda_{2} /$ total variance, a measure of the goodness of fit equivalent to $R^{2}$ (Jongman et al., 1987), was 0.9. As shown in Fig. 8, the shrub and herbaceous pollen types (i.e. Juniperus, Chenopodiaceae, Gramineae; Artemisia, and Rubiaceae), are correlated with $C$. lacustris. On the other hand, $C$. ophtalmica, M. cordata and Limnocytherinae sp. are correlated with pollen of thermophilous trees and shrubs (Corylus, Quercus ilex, Fraxinus, Quercus robur-type, and Ulmus). C. candida, Potamocypris (juveniles), and D. stevensoni are associated with the boreal-forest pollen types (Pinus sylvestris, P. cembra, and Betula), and also with Rumex acetosa/acetosella type.

Both Rumex acetosa/acetosella type and Alnus glutinosa pollen, which were weakly correlated to other species, presented low abundances in the pollen assemblages throughout the sequence.

Canonical analyses including ostracods and pollen of aquatic plants (4 taxa) did not produce satisfactory results since the first two RDA axes explained less than $50 \%$ of the total variance (Table 2 ).

Ordination techniques are exploratory analyses that provide useful tools for data interpretation. However, they are not designed to accept or reject hypotheses. Therefore the null hypothesis that no relationship exists between ostracod and pollen taxa was tested with a nonparametric Monte Carlo permutation test in order to evaluate the significance of the canonical axes. Monte Carlo permutations with specific restrictions for time-series analysis were used for both a test concerning only the first RDA axis and a second test including all eigenvalues. Both tests rejected the null hypothesis that no relationship exists between species and the environmental variables at $2 \%$ level of significance.

\section{Discussion}

The sampling strategy adopted in the present study was adjusted to assess the changes in ostracod assemblages in relation to periods of rapid changes in pollen composition. Accordingly interpretation of results actually aims at establishing whether changes in terrestrial vegetation were marked by periods of inferred changes in hydrology and/or in trophic level.

5.1. Palaeoenvironmental interpretation of ostracod and pollen biostratigraphies

The ostracod assemblages in the first ostracod biozone ( 01 ; $>14,200$ cal BP) were dominated by C. lacustris, indicating oligotrophic conditions with oxygenated waters (Geiger, 1990a; Danielopol et al., 1993). At the same time, a gradual afforestation with Betula was followed by an expansion of Pinus.

C. lacustris is considered a typical representative of the sublittoral to deep zone of large lakes, reaching its maximum abundances between 12 and 40 m water depths (Geiger, 1990b; Geiger, 1993). However, it has been found in shallow waters of some lakes in northern Europe and the 
British Isles (Delling, 1981; Fryer, 1993 in Meisch, 2000), indicating that the species is probably tolerant of a wide range of temperatures (Danielopol et al., 1993). In the sequence under study C. lacustris is present in a rich thanatocoenosis that is well structured in terms of the adult/juveniles ratio. This probably indicates that the living population was in optimal condition for the species development, not under a situation of stress. Therefore $C$. lacustris is considered in the present record as an indicator of sublittoral aquatic environments.

At the beginning of the second biozone (subzone 02a; 14,20012,750 cal yr BP) the total concentration of valves decreased, C. lacustris was strongly reduced, and $C$. candida and $C$. opthalmica dominated the ostracod assemblage. C. ophtalmica survives in waters with high concentration of organic matter (Meisch, 2000), while the retreat of C. lacustris in a modern alpine lake has been associated with low oxygen concentrations superposed on high organic or low porosity of the sediments (Danielopol and Casale, 1990). Therefore it is likely that the rise of $C$. ophtalmica and the contemporary retreat of $C$. lacustris were caused by the lowering of oxygen concentrations associated with increasing organic loads. Thermophilous trees expanded at the beginning of this zone, and Artemisia as well as Gramineae decreased, suggesting warmer conditions in contrast to the previous zone.

Total valve concentration and ostracod species abundance strongly decreased between 12,750 and 11,450 cal yr BP (subzone O2b Younger Dryas), indicating that the factor or the combination of factors (e.g. low temperatures, low oxygen concentration, or reduced availability of food) that curbed the abundance of ostracods reached its maximum influence. The occurrence of $D$. stevensoni suggests shallow water levels, and the presence of $M$. cordata in the transition phases at the beginning and the end of this biozone indicate shallow environments with aquatic vegetation. In the terrestrial environment, either colder or drier climatic conditions are indicated by the collapse of thermophilous arboreal taxa (e.g. Quercus) and the contemporary increase in shrub and herbaceous taxa (i.e. Juniperus, Artemisia, and Chenopodiaceae).

At the onset of the Holocene (Subzone 02c; 11,450-10,100 cal yr $\mathrm{BP})$, total valve abundance increased, indicating a gradual change in the aquatic environment that led to more favourable conditions for ostracods. After an abrupt increase, C. candida was progressively overcome by $C$. ophtalmica. The dominance of the latter species and the high abundance of valves indicate a gradual increase in the lake's trophic state, while the presence of $C$. lacustris and the contemporary decrease of littoral species ( $D$. stevensoni) at the top of the sequence testify to a lake-water level increase. The re-expansion of thermophilous trees indicates a climatic amelioration.

The estimated correspondence between ostracod zones and pollen biozones in the chrono- and biostratigraphic framework of Lago Piccolo di Avigliana proposed by Finsinger (2004) is reported in Table 3.

\subsection{Inferences from multivariate analyses}

The output of the PCA of the ostracod dataset is presented in Fig. 4. A well defined cluster, including samples in the ostracod biozone 01, is associated with $C$. lacustris and likely represents oxygenated waters with relatively low trophic level. On the left side of the diagram, a continuum of scores is scattered along the second axis. In the lower branch of the axis are placed sites dominated by $C$. candida (including

Table 3

Estimated correspondence between ostracod and pollen biozones in the chrono- and biostratigraphic framework of Lago Piccolo di Avigliana (modified from Finsinger, 2004)

\begin{tabular}{llll}
\hline Ostracod zones & Core depth $(\mathrm{cm})$ & Age $(\mathrm{yr}$ cal BP) & Pollen biozones \\
\hline AVP1 O2c & $<710$ & $<11500$ & Preboreal (Holocene) \\
AVP1 O2b & $755-710$ & $12500-11500$ & Younger Dryas \\
AVP1 O2a & $800-755$ & $14200-12500$ & Allerød \\
AVP1 01 & $>800$ & $>14200$ & Bølling \\
\hline
\end{tabular}

C. ophtalmica and Herpetocypris sp.), an assemblage that indicates warmer conditions with respect to the previous cluster and shallower waters with a higher trophic level. This group includes principally scores of subzone 02a and part of those of subzone 02c. The positive ramus of the second axis includes mainly scores of subzones $\mathrm{O} 2 \mathrm{~b}$ and part of those in subzone $02 \mathrm{c}$ and are associated with $D$. stevensoni, $C$. ophtalmica, M. cordata, Limnocytherinae sp. and Cyclocypris sp. This area of the diagram is heterogeneous for it includes samples with different total ostracod abundance and different ostracod assemblages. The dispersion of the samples in this subzone with respect to the second ordination axis suggests a time window with associated environmental variables in continuous evolution.

In the biplot diagram of the PCA on terrestrial pollen taxa there are three distinct clusters.

The first cluster, includes samples in subzone 01, with a pollen assemblage dominated by herbaceous vegetation indicating a cold terrestrial environment. The second cluster includes samples of subzones $\mathrm{O} 2 \mathrm{a}$ and $\mathrm{O} 2 \mathrm{~b}$ and represents an environment dominated by boreal forests, indicating a climatic amelioration with respect to the zone 01 . Although samples of subzones $02 \mathrm{~b}$ present more negative scores in the first axis than samples of subzone 02a, no discontinuity exists to justify their separation into two groups.

In the third cluster, where mainly samples of subzones 02c are included, thermophilous trees and shrubs clearly denote a climatic warming.

In both ostracod and pollen PCAs the first axis is by far the one that explains the major portion of the total variance. On the basis of the evidence provided by the pollen biostratigraphy, the first axis represents a strong environmental gradient likely associated with climatic warming between biozones 01 and 02 .

According to the ostracod analysis the first axis may be interpreted as warming, because of the presence of thermophilous species in the negative branch of the axis. However, considering that the ostracod assemblages indicate a transition from sublittoral and oxygenated waters to littoral conditions with higher contents in organic matter, the latent theoretical variable represented in this axis likely reflects also changes in the lake-water level and changes in the lake trophic level. Despite minor differences, the trend of the first axis scores plotted in stratigraphical sequence in the ostracod analysis is comparable with the one observed in pollen record.

On the other hand, ostracod sample scores on the second axis, which represent a small portion of the total variance, diverge from those of pollen especially in subzones $\mathrm{O} 2 \mathrm{~b}$ and $\mathrm{O} 2 \mathrm{c}$. The different arrangement of samples in the PCA biplots may either be due to the different responses of ostracod and vegetation assemblages to an external climatic forcing during a climatic change (namely the Younger Dryas) or to the fact that environmental factors affecting the terrestrial and the aquatic communities were different.

The shoreline in a small catchment basin like that of Lago Piccolo di Avigliana can be considered as an asymmetric boundary (sensu Margalef, 1986) where organic matter, nutrients, and clastic material, among others, move primarily from the terrestrial environment to the lake (Odum, 1983). This assumption provides the rational basis for a direct gradient ordination analysis with ostracod abundances as aquatic environmental response variables and pollen abundances as terrestrial environmental variables.

Major relationships between ostracod and pollen assemblages and environments associated with them according to canonical analysis (RDA) are summarized in Table 4.

In direct gradient analysis, constraining the ordination axes to reflect environmental information contained in pollen biostratigraphy results in a better discrimination of ostracod subzones O2a and O2c, but it does not affect the scattering and overlapping of samples in subzone $\mathrm{O} 2 \mathrm{~b}$ with the previous ones. This result confirms that the environmental interpretation of the second axis in the ostracod PCA is not the same as the one in pollen PCA and RDA. 
Table 4

Relationships between ostracod and pollen taxa and between different kinds of environments according to the RDA analysis

\begin{tabular}{|c|c|c|c|c|}
\hline Env. var. & $\begin{array}{l}\text { Terrestrial environment } \\
\text { (according to pollen) }\end{array}$ & Associated ostracod taxa & Ostracod zone & $\begin{array}{l}\text { Aquatic environment } \\
\text { (according to ostracods) }\end{array}$ \\
\hline Chenop t & Herbs and shrubs, forest opening & Cytherissa lacustris & 1 & $\begin{array}{l}\text { Oligotrophic, high oxygen concentration, cold, } \\
\text { relatively deep }\end{array}$ \\
\hline Pinus dipl. (Rum. acet.) & Boreal forest & $\begin{array}{l}\text { Candona candida, Darwinula stevensoni, } \\
\text { Herpetocypris sp., Potamocypris sp. }\end{array}$ & $2 a, 2 b$ & Oligo-mesotrophic shallow \\
\hline Ulmus (Aln. glt.) & Deciduous forest & $\begin{array}{l}\text { Cypria ophtalmica, Cyclocypris sp., } \\
\text { Metacypris cordata, Limnocytherinae sp., } \\
\text { Darwinula stevensoni }\end{array}$ & $2 c, 2 b$ & Shallow, mesotrophic, aquatic veget., warm \\
\hline
\end{tabular}

Differences between ostracod and pollen records, as inferred from the sample scores of the ordination analyses (Fig. 6), during the Younger Dryas may be related to a different reaction of these communities to that climate change. For ostracods, a condition of stress during the phase of low lake-water level possibly constrained populations to low abundances, while changes in terrestrial vegetation involved the retreat of some species (Quercus, Pinus) and the increase of cold-adapted species (Betula, Artemisia).

An alternative hypothesis to explain the differences between ostracod and pollen records takes changes in the water oxygen concentration into account. In the sequence under study sediments are composed of homogeneous fine detritus gyttia (FDG) with a relatively constant content of carbonates. Only sediments at 792-712 cm core depth (ca. 13,80011,500 cal yr BP) present partial laminations that may indicate a situation of limited circulation at the bottom of the water column possibly associated with a low oxygen concentration at the water-sediment interface. Oxygen limitation represents a factor of stress for ostracod populations that may lead to the disappearance of the most sensitive species at an initial stage and to the reduction in the total number of ostracods in case of more pronounced anoxia. Such processes that are limited to the water body would affect only aquatic populations contributing to uncoupling the response of terrestrial and aquatic communities to climatic forcing. The latter hypothesis is consistent with the low concentrations of $D$. stevenson $i$ in the middle of the Younger Dryas (12,500-11,700 cal yr BP) where re-deposition from shallower zones of the lake cannot be excluded.

On the other hand, the hypothesis of a low lake-water level during Y.D., based upon the presence of littoral ostracods, is consistent with the arid climatic conditions in the southern margin of the Alps reported in recent studies for this time window (Baroni et al., 2006, Frisia et al., 2005).

With the exception of the Younger Dryas, biozones defined on the basis of ostracod assemblages are well discriminated in the RDA diagram (Fig. 8) and are well correlated with specific terrestrial environmental conditions. On the other hand, the response of the ostracod community to climatic change during the Younger Dryas becomes evident in their total abundance rather than in changes in the species composition and is therefore poorly reflected in the ordination diagrams. In this regard the negative excursion of total absolute ostracod concentration matches quite well the shift of the thermophilous taxa Quercus deciduous type during the Younger Dryas (Figs. 2 and 3).

Very likely ordination techniques are little sensitive to changes in total ostracod abundance due to the kind of input data. The use of relative abundances makes multivariate analyses more sensitive to quantitative relationships among species. However, this kind of data does not reflect major changes in the total abundance of specimens in the community, which may provide environmental information about stress or favourable conditions.

\subsection{Comparison with other palaeoenvironmental studies}

In the maar lakes of the Eifel region (Germany) the most common species in the "early Lateglacial" (pre-Allerød) were C. lacustris and
Limnocytherina sanctipatricii (Scharf, 1993). During the Allerød a generalized increase in the number of species occurred, partly related to the development of submerged macrophytes, which provided food and protection for ostracods. In these lakes, no ostracods were present in post post-glacial sediments probably because of the decalcification of shells caused by eutrophication.

Ostracod and pollen biostratigraphies were both studied in a short late-glacial sequence extending from ca. 15,000 yr cal BP to the Laacher See Tephra (12,800 yr BP) in a palaeolake of the Eifel district (Scharf et al., 2005). In this site (Miesenheim) arboreal pollen was dominated by Betula and Pinus, which, however, expanded later than in the pollen record at Lago Piccolo di Avigliana (AVP). On the other hand, Artemisia pollen remained more or less stable throughout the sequence, while in AVP this taxon showed in the same time window a decreasing trend.

In Miesenheim the ostracod assemblages were more diverse and were composed exclusively of ostracods from shallow waters. The environmental reconstruction of the lake evolution indicates higher lake-water levels in the time window matching biozone 01 of AVP (Bølling) and a lowering of the lake-water level in correspondence with the first half of subzone O2a of the AVP record (Allerød). Because of the advent of adverse conditions in Miesenheim, ostracods disappeared from the record at the end of the Allerød. Hence the beginning of the ostracod depletion in Miesenheim coincides with the period of lower ostracod total abundance in AVP biozone O2b (Younger Dryas). The evolution of ostracod assemblages and the related environmental reconstruction in terms of changes in lake-water level in the lakes of the Eifel region are in general terms consistent with those observed in AVP.

A study of a sequence from Lake Neuchâtel (Switzerland) collected at $-40 \mathrm{~m}$ depth reports a major shift in the dominant species between late glacial and Holocene (Schwalb et al., 1994; Schwalb et al., 1998). During the Bølling the assemblage dominated by L. sanctipatricii and Leucocythere mirabilis and including also C. lacustris indicates a deep, cold, oligotrophic lake. In the Allerød, C. lacustris was replaced by C. neglecta, a species more tolerant to lower oxygen concentrations and to the increase in water temperature. In these biozones the environmental reconstructions are consistent with those of the present study. On the other hand, in contrast with AVP, ostracod abundances in the Younger Dryas, in particular L. sanctipatricii, L. mirabilis and C. lacustris reached a maximum.

During the Preboreal these three species collapsed and were replaced by $C$. neglecta, a species that prefers cold environments but is present in a wide range of habitats.

In addition to the lake size and the coring depth, differences between the late-glacial sequence of AVP and the one in Lake Neuchâtel may be related to the input of glacial meltwater in the latter lake. The discharge of the Aar River into Lake Neuchâtel contributed to the mixing and the oxygenation of hypolimnetic waters. The authors concluded that the Younger Dryas was characterized by warm and dry summers, which would have had a negative influence on the precipitation-evaporation balance.

A comparison that includes ostracod and pollen data dating back to $12,000 \mathrm{yr}$ B.P. is available for Lake Mondsee (Austria) in a core retrieved from the littoral of the lake (Handl, 1989). According to this study the full-glacial assemblage dominated by C. lacustris was 
replaced after the Bølling/Allerød transition by a fauna dominated by C. candida, Cyclocypris ovum and L. sanctipatricii. This community remained at very low densities during the Younger Dryas and had a peak abundance at the beginning of the Preboreal. Except for the low abundances of macrophytes, the resemblance with the sequence of AVP is remarkable.

\section{Conclusions}

According to numerical analyses and ordination diagrams major changes in the species composition occurred in both ostracod and vegetation assemblages between the late glacial and the early Holocene ( 16,000-10,000 cal. yr BP). These changes are reflected in the first ordination axes and are certainly related to climatic warming, which in the aquatic ecosystem is expressed as changes in hydrology (lake-water level) and in the trophic level, especially oxygen concentrations.

The evolution from Allerød to Preboreal in the terrestrial environment may be summarized as a transition from boreal forests to thermophilous forests interrupted by the Younger Dryas. At the same time in the aquatic environment there was a slight increase in the trophic level associated with the development of aquatic vegetation. During the Younger Dryas, a time window with high rate of change, ostracod communities were unstable and were likely influenced by stress. The response of the ostracod community to climatic forcing in this stadial is confined to changes in their total abundance rather than changes in the species composition. The negative excursion in the ostracod total abundance, however, is poorly reflected by the ordination techniques for the input data are relative abundances. With the exception of the Younger Dryas, biozones defined on the basis of ostracod assemblages are well discriminated in the RDA diagram and are well correlated with specific terrestrial environmental conditions.

Late-glacial ostracod assemblages in Lago Piccolo di Avigliana (Italian Prealps) are altogether comparable with those in sites in the north of the Alps and in Central Europe, if the influence of local factors (latitude, hydrology, lake morphometry, etc.) are duly taken into consideration. The latter suggests a common pattern at a wide geographical scale in the response of aquatic ecosystems to the climatic changes during the late glacial-Holocene transition. From a biogeographic point of view the wide distribution over Europe of $C$. lacustris in the assemblages corresponding to the Bølling biozones is striking.

Multivariate analyses highlight relationships between species and samples, reinforcing the environmental reconstruction obtained with a discretional biostratigraphical approach. The contribution of numerical techniques was particularly useful in choosing between evenly ranked alternative hypotheses. Eliminating noisy and redundant information contributed to the identification of associations between ostracod and pollen taxa and their environments. Hypothesis testing with Monte Carlo permutations with specific constraints for time-series analysis rejected the null hypothesis that no relationship exists between ostracod and pollen assemblages.

\section{Acknowledgments}

We are grateful to Willy Tinner, Aldo Marchetto, Piero Guilizzoni, Frank Oldfield, and Herb Wright Jr. for their suggestions and helpful comments. The criticism and the suggestions of the reviewers contributed to improve the original version of the manuscript.

\section{References}

Ammann, B., Birks, H.J.B., Brooks, S.J., Eicher, U., Eicher, U., von Grafenstein, U., Hofmann, W., Lemdahl, G., Schwander, J., Tobolski, K., Wick, L, 2000. Quantification of biotic responses to rapid climatic changes around the Younger Dryas - a synthesis. Palaeogeography, Palaeoclimatology, Palaeoecology 159, 313-347.

Anadón, P., De Deckker, P., Julià, R.,1986. The Pleistocene lake deposits of the NE Baza Basin (Spain): salinity variations and ostracod succession. Hydrobiologia 143, 199-208.
Anderson, N.J., Odgaard, B.V., Segerström, U., Renberg, I., 1996. Climate-lake interactions recorded in varved sediments from a Swedish boreal forest lake. Global Change Biology 2, 399-403.

Baales, M., Jöris, O., Street, M., Bittmann, F., Wiethold, J., 2002. Impact of the Late Glacial eruption of the Laacher See volcano, Central Rhineland, Germany. Quaternary Research 58, 273-288.

Baroni, C., Zanchetta, G., Fallick, A.E., Longinelli, A., 2006. Mollusc stable isotope record of a core from Lake Frassino, northern Italy: hydrological and climatic changes during the last $14 \mathrm{k}$. The Holocene 16, 827-837.

Belis, C.A., Lami, A., Guilizzoni, P., Ariztegui, D., Geiger, W., 1999. The late Pleistocene ostracod record of the crater lake sediments from Lago di Albano (Central Italy): changes in trophic status, water level and climate. Journal of Paleolimnology 21, 151-169.

Bennett, K.D., 1996. Determination of the number of zones in a biostratigraphica sequence. New Phytologist 132, 155-170.

Biancotti, A., Bellardone, G.S.B., Cagnazzi, B., Giacomelli, L., Marchisio, C., 1998. Regional distribution of rainfalls and temperatures. Climatological Studies in Piedmont 1,1-80.

Birks, H.J.B., Gordon, D.A., 1985. Numerical Methods in Quaternary Pollen Analysis Academic Press, London. 289 pp.

Blockley, S.P.E., Pyne-O'Donnell, S.D.F., Lowe, J.J., Matthews, I.P., Pollard, A.M., Turney C.S.M., Molyneux, E.G., 2005. A new and less destructive laboratory procedure for the physical separation of distal glass tephra shards from sediments. Quaternary Science Reviews 24, 1952-1960.

Boomer, I., Horne, D.J., Slipper, I.J., 2003. The use of ostracods in paleoenvironmental studies or what can you do with an ostracod shell? Paleontological Society Papers 9, 153-180.

Carraro, F., Cadoppi, P., Castelletto, M., Sacchi, R., Baggio, P., Giraud, V., Bellardone, G., 2002 Note Illustrative della Carta Geologica d'Italia alla scala 1:50 000, Foglio 154 - Susa. Regione Piemonte, Torino, 127 pp.

Colman, S.M., Forester, R.M., Reynolds, R.L., Sweerkind, D.S., King, J.W., Gangemi, P., Jones, G.A., Keigwin, L.D., Foster, D.S., 1994. Lake level history of Lake Michigan for the past 12,000 years: the record from deep lacustrine sediments. Journal of Great Lakes Research 20, 73-92.

Corsten, L.C.A., Gabriel, K.R., 1976. Current statistical issues in agricultural research. Statistica Neerlandica 39, 159-168.

Curry, B.B., 1999. An environmental tolerance index for ostracodes as indicators of physical and chemical factors in aquatic habitats. Palaeogeography, Palaeoclimatology, Palaeoecology 148, 51-63.

Danielopol, D., Casale, L., 1990. Long-, short-term perturbations of the Cytherissa lacustris population in Mondsee: a paleolimnological perspective. Bulletin de l'Institute de Geologie Bassin d'Acquitaine Boredaux 47, 209-226.

Danielopol, D., Handl, M., Yin, Y., 1993. Benthic ostracods in the prealpine deep lake Mondsee. Notes on their origin and distribution. In: McKenzie, K.G., Jones, P.J. (Eds.) Ostracoda in the Earth and Life Sciences. Balkema, Rotterdam, pp. 465-480.

Delling, D., 1981. Eutrophierungseffekte an Ostracodengemeinschaften oligohaliner Gewässer Norddeutschlands. Unpublished Dissertation. University of Kiel, 265pp.

Finsinger, W., 2004. Forest dynamics under changing climates: History of vegetation and climate in Northwestern Italy. Unpubl. PhD Thesis, University of Bern, Bern, 102 pp.

Finsinger, W., Tinner, W., van der Knaap, W.O., Ammann, B., 2006. The expansion of hazel (Corylus avellana L.) in the southern Alps: a key for understanding its early Holocene behaviour in Europe? Quaternary Science Reviews 21, 243-258.

Frisia, S., Borsato, A., Spötl, C., Villa, I.M., Cucchi, F., 2005. Climate variability in the SE Alps of Italy over the past 17000 years reconstructed from a stalagmite record. Boreas 34, 445-455.

Fryer, G., 1993. The freshwater Crustacea of Yorkshire. A faunistic and ecological survey Yorkshire Naturalists Union and Leeds Philosophical and Literary Society. 312 pp.

Gaggino, G.F., Cappelletti, E., 1984. Catasto dei laghi italiani. Italia settentrionale Quaderni I.R.S.A., vol. 1. C.N.R., Roma. 970 pp.

Geiger, W., 1990a. The role of oxygen in the disturbance and recovery of the Cytheriss lacustris population of Mondsee (Austria). Bulletin de l'Institute de Geologie Bassin d'Acquitaine Boredaux 47, 167-189.

Geiger, W., 1990b. Field and laboratory studies on the life cycle of Cytherissa lacustris (Sars) with special emphasis on the role of temperature. Bulletin de l'Institute de Geologie Bassin d'Acquitaine 47, 191-208.

Geiger, W., 1993. Cytherissa lacustris (Ostracoda, Crustacea): its use in detecting and reconstructing environmental changes at the sediment-water interface. Verhandlungen, Internationale Vereinigung für Theoretische und Angewandte Limnologie 25, 1102-1107.

Handl, 1989. Paläolimnologische Untersuchungen an spät- und postglazialen Sedimenten des Halles- wies- und Mondsees (Oberösterreich) (Palynologie und Ostracoda). PhD Thesis, Universitiy of Salzburg. 210 pp.

Hiller, D., 1972. Untersuchumgen zur Biologie und zur Ökologie limnischer Ostracoden aus der Umgebung von Hamburg. Archiv für Hydrobiologie Supplement-Band 40 400-497.

Jongman, R.H.G., ter Braak, C.J.F., van Tongeren, O.F.R. (Eds.), 1987. Data analysis in community and landscape ecology. Pudoc Wageningen, The Nederlands. 299 pp.

Löffler, H., 1997. The role of ostracods for reconstructing climatic change in Holocene and Late Pleistocene lake environment in Central Europe. Journal of Paleolimnology $18,29-32$.

Lotter, A.F., 1988. Paläoökologische und Paläolimnologische Studie des Rotsees bei Luzern. Unpubl. PhD Thesis, Universität Bern. Bern. 227 pp.

Lotter, A.F., 2004. Multi-proxy climatic reconstructions. In: Mackay, A.W., Battarbee R.W., Birks, H.J.B., Oldfield, F. (Eds.), Global change in the Holocene. Arnold Publisher, London, pp. 371-383.

Lowe, J.J., 2001. Climatic oscillations during the Last Glacial cycle - nature, causes and the case for synchronous effects. Proceedings of the Royal Irish Academy 101B, 19-33. 
Mangerud, J., Andersen, S.T., Berglund, B.E., Donner, J.J., 1992. Quaternary stratigraphy of Norden, a proposal for terminology and classification. Boreas 3, 109-128.

Manly, B.F.J., 1992. The Design and Analysis of Research Studies. Cambridge University Press, Cambridge, pp. 286-311.

Margalef, R., 1986. Ecologia. Omega, Barcelona. 951 pp.

Meisch, C., 2000. Freshwater Ostracoda of Western and Central Europe. Spektrum Akademischer. Verlag, Heidelberg Berlin. 522 pp.

Merkt, J., Streif, H., 1970. Stechrohr-Bohrgeräte für limnische und marine Lockersedimente. Geologische Jahrbücher 88, 137-148.

Mezquita, F., Hernández, R., Rueda, J., 1999. Ecology and distribution of ostracods in a polluted Mediterranean river. Palaeogeography, Palaeoclimatology, Palaeoecology 148, 87-103.

Moore, P.D., Webb, J.A., 1978. An Illustrated Guide to Pollen Analysis. Hodder and Stoughton, London.

Mourguiart, P., Carbonel, P., 1994. A quantitative method of palaeolake-leve reconstruction using ostracod assemblages: an example from the Bolivian Altiplano. Hydrobiologia 288, 183-193.

Nüchterlein, H., 1969. Süßwasserostracoden aus Franken. Ein Beitrag zur Systematik und Ökologie der Ostracoden. Internationale Revue der gesamten Hydrobiologie 54, 223-287.

Odum, E.P., 1983. Basic Ecology. CBS College Publishing. 544 pp.

Petrucci, F., Bortolami, G.C., Dal Piaz, G.V., 1970. Ricerche sull'Anfiteatro morenico di Rivoli-Avigliana (Provincia di Torino) e sul suo substrato cristallino. Memorie della Società Italiana di Scienze Naturali e del Museo Civico di Storia Naturale di Milano $18,95-168$.

Punt, W., Blackmore, S., Clarke, G.C.S., 1976-1996. Northwest European Pollen Flora: vol 1 (1976); vol 2 (1980); vol 3 (1981); vol 4 (1984); vol 5 (1988); vol 6 (1991); vol 7 (1996). Elsevier, Amsterdam.

Reille, M., 1992. Pollen et spores d'Europe et d'Afrique du nord. Laboratoire de Botanique Historique et Palynologie, Marseille. 520 pp.

Scharf, B.W., 1993. Ostracoda (Crustacea) form eutrophic and oligotrophic maar lakes of the Eifel (Germany) in the Late and Post Glacial. In: McKenzie, K.G. Jones, P.J. (Eds.), Ostracoda in Earth and Life Sciences. Proceedings of the 11th
International Symposium on Ostracoda Warrnambool, Australia. A.A. Balkema, Rotterdam, pp. 453-464

Scharf, B.W., 1998. Eutrophication history of Lake Arendsee (Germany). Palaeogeography, Palaeoclimatology, Palaeoecology 140, 85-96.

Scharf, B.W., Bittmann, F., Boettger, T., 2005. Freshwater ostracods (Crustacea) from the Lateglacial site at Miesenheim, Germany, and temperature reconstruction during the Meiendorf Interstadial. Palaeogeography, Palaeoclimatology, Palaeoecology 225, 203-215.

Schwalb, A., Hadorn, P., Thew, N., Straub, F., 1998. Evidence for Late-Glacial and Holocene environmental changes from subfossil assemblages and sediments of Lake Neuchâtel, Switzerland. Palaeogeography, Palaeoclimatology, Palaeoecology 140, 307-323.

Schwalb, A., Lister, G., Kelts, K., 1994. Ostracod carbonate 180 and 13C- signatures of hydrological and climate changes affecting Lake Neuchâtel, Switzerland, since the latest Pleistocene. Journal of Paleolimnology 11, 3-17.

Schwander, J., Eicher, U., Ammann, B., 2000. Oxygen isotopes of lake marl at Gerzensee and Leysin (Switzerland), covering the Younger Dryas and two minor oscillations, and their correlation to the GRIP ice core. Palaeogeography, Palaeoclimatology, Palaeoecology 159, 203-214.

Stockmarr, J., 1971. Tablets with spores used in absolute Pollen Analysis. Pollen et Spores 13, 615-621.

ter Braak, C.J.F., Prentice, C., 1988. A theory of gradient analysis. Advances in Ecological Research 18, 271-317.

ter Braak, C.J.F., Šmilauer, P., 2003. CANOCO Reference Manual and CanoDraw for Windows User's Guide: Software for Canonical Community Ordination (version 4.5). Centre for Biometry Wageningen, Ithaca, NY, USA

Trautmann, W., 1953. Zur Unterscheidung fossiler Spaltöffnungen der mitteleuropäischen Coniferen. Flora 140, 523-533.

Van Morkhoven, F.P.C.M., 1962. Post-Paleozoic Ostracoda. Their morphology, taxonomy and economic use, vol. 1. Elsevier. 204 pp. 